\title{
A Study of Some Strontium Aluminates and Calcium- Strontium Aluminate Solid Solutions
}

\author{
Elmer T. Carlson
}

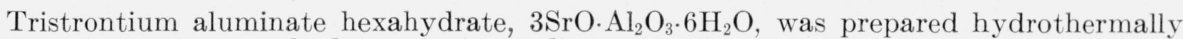
as well as by various methods employing ordinary temperatures and atmospheric pressure. It crystallizes in the isometric system, with a unit cell edge of $13.04 \mathrm{~A}$, and has a refractive index of 1.588. It is isomorphous with $3 \mathrm{CaO} \cdot \mathrm{Al}_{2} \mathrm{O}_{3} \cdot 6 \mathrm{H}_{2} \mathrm{O}$, and a complete series of solid solutions exists between the two. No evidence was found of hexagonal hydrated strontium aluminates analogous to those of calcium. Tristrontium aluminate hexahydrate is stable up to about $454^{\circ} \mathrm{C}$ at 420 atmospheres water vapor pressure. One of the products of hydrothermal decomposition appears to have the composition $5 \mathrm{SrO}_{4} 4 \mathrm{Al}_{2} \mathrm{O}_{3}$. This compound breaks down on being heated, forming $\mathrm{SrO} \cdot \mathrm{Al}_{2} \mathrm{O}_{3}$ and $3 \mathrm{SrO} \cdot \mathrm{Al}_{2} \mathrm{O}_{3}$. Attempts to prepare a strontia-alumina-silica hydrogarnet were unsuccessful.
\end{abstract}

\section{Introduction}

As a result of numerous investigations $[1,2,3]^{1}$ of chemical reactions related to the hardening of hydraulic cements, it is known that lime and alumina in solution may combine to form an isometric tricalcium aluminate hexahydrate, $3 \mathrm{CaO} \cdot \mathrm{Al}_{2} \mathrm{O}_{3} \cdot 6 \mathrm{H}_{2} \mathrm{O}$. Flint, McMurdie, and Wells [2] showed that this compound is isomorphous with grossularite garnet, $3 \mathrm{CaO} \cdot \mathrm{Al}_{2} \mathrm{O}_{3}$. $3 \mathrm{SiO}_{2}$, and that there is a solid solution series between them.

Although strontia is a relatively minor constituent of cement, the compounds it may be expected to form with silica, alumina, and water, at both ordinary and elevated temperatures, are of some interest. The strontium silicates have been discussed in a previous paper [4]. The existence of tristrontium aluminate hexahydrate has been reported by Brandenberger [5] and by Maekawa [6]. The latter gave data relative to its structure and thermal decomposition.

\section{Materials and Procedure}

Reagent grade chemicals were used without further purification except in the case of strontium hydroxide, which was recrystallized to remove carbonate. The alumina used was a commercial preparation of gibbsite $\left(\mathrm{Al}_{2} \mathrm{O}_{j} \cdot 3 \mathrm{H}_{2} \mathrm{O}\right)$ containing about 0.30 percent of $\mathrm{Na}_{2} \mathrm{O}$; other impurities were negligible in amount.

Pressure bombs of the Morey type were employed for the hydrothermal work. These were of stainless steel, with a capacity of about $18 \mathrm{ml}$. The reaction mixture was placed in a platinum thimble, to minimize contamination, and in most cases was made up to a paste with water. Pressure was dependent on the temperature and the quantity of water in the bomb. For temperatures below the critical point, excess liquid water was present, except as otherwise noted. The pressures indicated in the tables were calculated from steam tables for the lower temperatures, and from the pressure-volume-temperature data of Kennedy [7] for the bigher temperatures used.

${ }^{1}$ Figures in brackets indicate the literature references at the end of this paper.
The pressure values given are only approximate, as they are not corrected for such calculable factors as thermal expansion of the bomb, nor for the unknown effects of dissolved solids in the liquid and vapor phases and the hydration of the solids. Temperatures were maintained constant within \pm 2 deg., and the temperatures reported herein are probably accurate within $\pm 5 \mathrm{deg}$.

In general, the reaction products were filtered, washed with alcohol and ether, and examined with a petrographic microscope. No special precautions were taken to avoid carbonation, either during the hydrothermal treatment or during the filtration. Carbonate, when present, was readily distinguishable under the microscope, but the amounts present were considered negligible. X-ray powder diffraction patterns were made, as needed, using a recording X-ray diffractometer with copper $K \alpha$ radiation. Chemical analyses, when required, were made by conventional methods, water being calculated from the ignition loss, and strontium determined as the sulfate.

\section{Experimental Results}

\subsection{Tristrontium Aluminate Hexahydrate}

Tristrontium aluminate hexahydrate $\left(3 \mathrm{SrO} \cdot \mathrm{Al}_{2} \mathrm{O}_{3}\right.$.$\left.6 \mathrm{H}_{2} \mathrm{O}\right)$ was prepared by the following methods: (1) Addition of aluminum chloride solution, slowly, to a boiling solution of strontium hydroxide. The product was well crystallized in the form of cubes and octahedra, many of the latter having rounded knobs at the corners. (2) Action of strontium hydroxide solution on freshly precipitated alumina gel. The reaction was rapid at the boiling temperature, and the product was predominantly cubic in habit, as shown in figure 1. At room temperature the reaction was much slower. (3) Treatment of gibbsite with boiling strontium hydroxide. The product crystallized as dodecahedra, but the reaction was incomplete even after boiling overnight. (4) $\mathrm{Hy}-$ drothermal treatment of a gibbsite-strontium hydroxide mixture. The reaction was essentially complete after 7 days at $155^{\circ} \mathrm{C}$ (see table 1). (5) Hydrothermal treatment of anhydrous tristrontium alumi- 


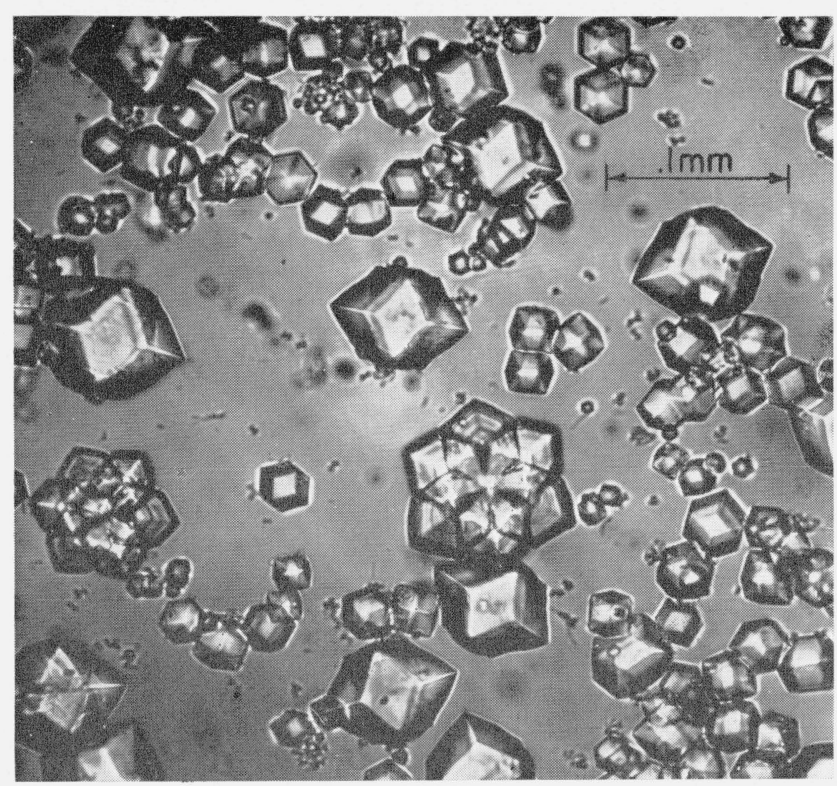

FIgURE 1. Crystals of $3 \mathrm{SrO} \cdot \mathrm{Al}_{2} \mathrm{O}_{3} \cdot 6 \mathrm{H}_{2} \mathrm{O}$ prepared by the action of boiling strontium hydroxide solution on alumina gel.

nate at 164 to $440^{\circ} \mathrm{C}$. The crystals were generally cubic in shape, but with rounded edges.

In none of these experiments was there any evidence obtained of a hexagonal aluminate such as is formed by calcium. Apparently strontium forms only the isometric hydrated aluminate.

Tristrontium aluminate hexahydrate is isomorphous with the corresponding calcium compound. This is shown by the X-ray diffraction patterns which indicate the same reflecting planes with such changes in relative intensities as might be expected from isomorphous substitution. There is also a shift in the lines corresponding to a somewhat larger unit cell for the strontium compound. The lattice constant for the latter is calculated to be $13.04 \mathrm{~A}$, as compared with 12.57. the generally accepted figure for the calcium analog. Maekawa [6] reported a unit cell edge of 13.10 A for the strontium compound. The index of refraction determined in this study was 1.588 , in agreement with the figure reported by Maekawa.

The hydrothermal decomposition of $3 \mathrm{CaO} \cdot \mathrm{Al}_{2} \mathrm{O}_{3}$. $6 \mathrm{H}_{2} \mathrm{O}$ to $4 \mathrm{CaO} \cdot 3 \mathrm{Al}_{2} \mathrm{O}_{3} \cdot 3 \mathrm{H}_{2} \mathrm{O}$ was reported by Thorvaldson [8], and confirmed by Peppler and Wells [9], who placed the decomposition temperature at about $215^{\circ} \mathrm{C}$ in the presence of saturated steam. The strontium compound, $3 \mathrm{SrO} \cdot \mathrm{Al}_{2} \mathrm{O}_{3} \cdot 6 \mathrm{H}_{2} \mathrm{O}$, proved to have a higher range of stability, but the nature of the breakdown and the conditions affecting it are not at all clear. Experiments intended to be duplicates sometimes gave rise to quite dissimilar products. Apparently the decomposition may occur in at least three different ways.

The first consists of a breakdown to $\mathrm{Sr}(\mathrm{OH})_{2}$ and an unidentified crystalline compound. This occurred incompletely in experiment 9, and completely in experiments 13 and 14 , table 1 . In experiment 9 , the temperature was $305^{\circ} \mathrm{C}$, and there was no water in the reaction vessel except the small amount resulting from the decomposition. The reaction was still incomplete after 4 days. In experiments 13 and 14 , the reaction appeared to be complete after 7 days at about $450^{\circ} \mathrm{C}$. In this pair of experiments the amount of water in the vessel, and hence the pressure, was greater in experiment 14 than in No. 13 , but the results were the same. The ovendried charge was weighed before and after the hydrothermal treatment to determine the loss of water from the solid. Consideration of hypothetical reactions that would result in a water loss approximating that observed (3.4 moles) leads to the conclusion that the unknown phase is either an anhydrous form of alumina or a strontium aluminate, possibly a low hydrate, relatively low in strontium. Its X-ray diffraction pattern does not fit any of the published patterns for anhydrous forms of alumina or the known strontium aluminates. It dissolves readily in $N / 20 \mathrm{HCl}$, hence, it cannot be separated from the strontium hydroxide by this means. This decomposition mechanism appears to be favored by low pressure.

A second process involves the formation of an anhydrous strontium aluminate believed to have the

TABLE 1. Hydrothermal synthesis and decomposition of tristrontium aluminate hexahydrate

\begin{tabular}{|c|c|c|c|c|c|}
\hline $\begin{array}{l}\text { Experi- } \\
\text { ment }\end{array}$ & Reactants (solid) & $\begin{array}{l}\text { Temper- } \\
\text { ature }\end{array}$ & Pressure & Time & Products \\
\hline $\begin{array}{l}1 \\
2\end{array}$ & $3\left(\mathrm{Sr}(\mathrm{OH})_{2} \cdot 8 \mathrm{H}_{2} \mathrm{O}\right)+\mathrm{Al}_{2} \mathrm{O}_{3} \cdot 3 \mathrm{H}_{2} \mathrm{O}$ & $\begin{array}{l}{ }^{\circ} \mathrm{C} \\
155 \\
452\end{array}$ & $\begin{array}{r}\text { atm } \\
5 \\
410\end{array}$ & $\begin{array}{c}\text { Days } \\
7 \\
7\end{array}$ & $\begin{array}{l}3 \mathrm{SrO} \cdot \mathrm{Al}_{2} \mathrm{O}_{3} \cdot 6 \mathrm{H}_{2} \mathrm{O} \text {. } \\
3 \mathrm{SrO} \cdot \mathrm{Al}_{2} \mathrm{O}_{3} \cdot 6 \mathrm{H}_{2} \mathrm{O} \text { (reaction incomplete). }\end{array}$ \\
\hline $\begin{array}{l}3 \\
4 \\
5 \\
6 \\
7\end{array}$ & $\begin{array}{l}3 \mathrm{SrO} \cdot \mathrm{Al}_{2} \mathrm{O}_{3} \\
\mathrm{~d} \mathrm{do}_{2}\end{array}$ & $\begin{array}{l}164 \\
303 \\
440 \\
454 \\
518\end{array}$ & $\begin{array}{r}5 \\
90 \\
380 \\
420 \\
560\end{array}$ & $\begin{array}{l}3 \\
4 \\
1 \\
3 \\
3\end{array}$ & $\begin{array}{l}3 \mathrm{SrO} \cdot \mathrm{Al}_{2} \mathrm{O}_{3} \cdot 6 \mathrm{H}_{2} \mathrm{O} \\
\text { Do. } \\
\text { Do. } \\
5 \mathrm{SrO} \cdot 4 \mathrm{Al}_{2} \mathrm{O}_{3}+\mathrm{Sr}(\mathrm{OH})_{2} \\
\text { Do. }\end{array}$ \\
\hline $\begin{array}{r}8 \\
9 \\
10\end{array}$ & $3 \mathrm{SrO} \cdot \mathrm{Al}_{2} \mathrm{O}_{3} \cdot 6 \mathrm{H}_{2} \mathrm{O}$ & $\begin{array}{l}258 \\
305 \\
397\end{array}$ & $\begin{array}{r}2 \\
2 \\
40\end{array}$ & $\begin{array}{l}4 \\
4 \\
7\end{array}$ & $\begin{array}{l}3 \mathrm{SrO} \cdot \mathrm{Al}_{2} \mathrm{O}_{3} \cdot 6 \mathrm{H}_{2} \mathrm{O} \text { (no apparent change). } \\
3 \mathrm{SrO} \cdot \mathrm{Al}_{2} \mathrm{O}_{3} \cdot 6 \mathrm{H}_{2} \mathrm{O}+\mathrm{Sr}(\mathrm{OH})_{2}+\text { an unidentified phase. } \\
3 \mathrm{SrO} \cdot \mathrm{Al}_{2} \mathrm{O}_{3} \cdot 6 \mathrm{H}_{2} \mathrm{O}+\mathrm{Sr}(\mathrm{OH})_{2}+\text { " } 3 \mathrm{SrO} \cdot \mathrm{Al}_{2} \mathrm{O}_{3} \cdot 1.5 \mathrm{H}_{2} \mathrm{O} \text { " }+ \text { an unidentified } \\
\quad \text { phase; lost } 2.9 \text { moles } \mathrm{H}_{2} \mathrm{O} \text {. }\end{array}$ \\
\hline $\begin{array}{l}11 \\
12 \\
13 \\
14 \\
15 \\
16\end{array}$ & 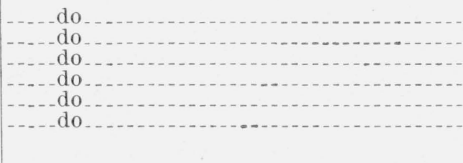 & $\begin{array}{l}402 \\
402 \\
453 \\
449 \\
508 \\
513\end{array}$ & $\begin{array}{r}130 \\
280 \\
40 \\
150 \\
540 \\
550\end{array}$ & $\begin{array}{l}7 \\
4 \\
7 \\
7 \\
8 \\
8\end{array}$ & $\begin{array}{l}3 \mathrm{SrO} \cdot \mathrm{Al}_{2} \mathrm{O}_{3} \cdot 6 \mathrm{H}_{2} \mathrm{O} \text {; probably some } \mathrm{Sr}(\mathrm{OH})_{2} . \\
3 \mathrm{SrO} \cdot \mathrm{Al}_{2} \mathrm{O}_{3} \cdot 6 \mathrm{H}_{2} \mathrm{O} \text { (no apparent change). } \\
\mathrm{Sr}(\mathrm{OH})_{2}+\text { unidentified phase; lost } 3.4 \text { moles } \mathrm{H}_{2} \mathrm{O} \text {. } \\
\mathrm{Sr}(\mathrm{OH})_{2}+\text { unidentified phase; lost } 3.4 \text { moles } \mathrm{H}_{2} \mathrm{O} \text {. } \\
5 \mathrm{SrO} \cdot 4 \mathrm{Al}_{2} \mathrm{O}_{3}+\mathrm{Sr}(\mathrm{OH})_{2} \text {. } \\
\text { " } 3 \mathrm{SrO} \cdot \mathrm{Al}_{2} \mathrm{O}_{3} \cdot 1.5 \mathrm{H}_{2} \mathrm{O} \text { "; small amounts of } \mathrm{Sr}(\mathrm{OH})_{2} \text { and an unidentified } \\
\text { phase; lost } 4.2 \text { moles } \mathrm{H}_{2} \mathrm{O} \text {. }\end{array}$ \\
\hline
\end{tabular}


composition $5 \mathrm{SrO} \cdot 4 \mathrm{Al}_{2} \mathrm{O}_{3}$. Because of its coarse crystalline habit it can be separated readily from the matrix of strontium hydroxide. It will be described more completely in the following section. As indicated in table 1 , this compound was obtained at temperatures ranging from $454^{\circ}$ to $518^{\circ} \mathrm{C}$ (experiments $6,7,15)$.

The third process of decomposition is exemplified by experiment 16 in table 1 . The conditions here were intermediate between those of experiments 7 and 15 , both of which yielded the 5:4 compound described above, but in No. 16 the result was quite different. The major part of the product, perhaps 90 percent, consisted of isotropic crystals, similar in size to those of the original material, but having a refractive index of 1.603. A very sharp X-ray diffraction pattern was obtained, the spacings indicating a body-centered cubic lattice with unit cell edge of $9.47 \mathrm{~A}$. The pattern also contained a few very weak lines of $\mathrm{Sr}(\mathrm{OH})_{2}$ and one weak unidentified line. From microscopic and X-ray evidence, it was estimated that the preparation was about 90 percent one phase. The water remaining in combination amounted to about 1.8 moles. An arbitrary allowance for the water in the $\mathrm{Sr}(\mathrm{OH})_{2}$ reduces this to about 1.5 moles, from which the composition of the new crystalline phase is concluded to be $3 \mathrm{SrO}$. $\mathrm{Al}_{2} \mathrm{O}_{3} \cdot 1.5 \mathrm{H}_{2} \mathrm{O}$. Numerous unsuccessful attempts were made to duplicate preparation 16 . The X-ray patterns for No. 10, and for at least one other preparation not recorded in table 1 , showed the presence of the same compound, but mixed with other phases. Neither of these was sufficiently pure to permit a determination of the composition; hence, the formula is not established with certainty.

The fact that the hypothetical compound $3 \mathrm{SrO} \cdot \mathrm{Al}_{2} \mathrm{O}_{3} \cdot 1.5 \mathrm{H}_{2} \mathrm{O}$ is not readily obtained may indicate that it is not very stable. As a reasonable explanation for the conflicting data on the decomposition of $3 \mathrm{SrO} \cdot \mathrm{AJ}_{2} \mathrm{O}_{3} \cdot 6 \mathrm{H}_{2} \mathrm{O}$ under hydrothermal conditions it is suggested that the third process described, involving merely a loss of water, may actually occur first, followed more or less quickly by a breakdown to strontium hydroxide and some form of alumina or anhydrous strontium aluminate, and finally by a recombination to the anhydrous $5 \mathrm{SrO} \cdot 4 \mathrm{Al}_{2} \mathrm{O}_{3}$.

The decomposition of the hexahydrate in air has not been thoroughly studied, but differential thermal analysis indicates that the water is driven off between $280^{\circ}$ and $700^{\circ} \mathrm{C}$. Determination of free strontia by the glycerol-alcohol method [10] showed evidence of some liberation of strontia after an hour's heating at $400^{\circ} \mathrm{C}$, but none after an hour at $700^{\circ} \mathrm{C}$. X-ray diffraction analysis proved that the sample held at $700^{\circ}$ had been converted to anhydrous tristrontium aluminate.

\section{2. $5 \mathrm{SrO} \cdot 4 \mathrm{Al}_{2} \mathrm{O}_{3}$}

Among the products of the hydrothermal decomposition of $3 \mathrm{SrO} \cdot \mathrm{Al}_{2} \mathrm{O}_{3} \cdot 6 \mathrm{H}_{2} \mathrm{O}$ at 454 to $518^{\circ} \mathrm{C}$, the one most readily distinguished appeared in the form

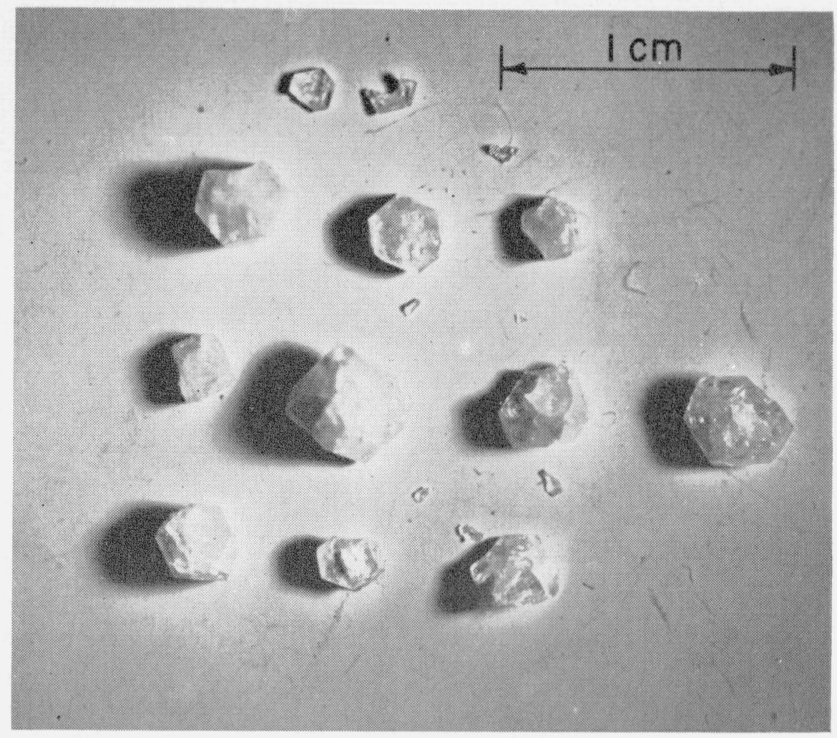

Figure 2. Crystals of $5 \mathrm{SrO} \cdot 4 \mathrm{Al}_{2} \mathrm{O}$.

of short hexagonal prisms up to $2 \mathrm{~mm}$ in size (see fig. 2). Because of the large size of the crystals, they could readily be separated by hand from the rest of the material (consisting of strontium hydroxide and sometimes undecomposed $3 \mathrm{SrO} \cdot \mathrm{Al}_{2} \mathrm{O}_{3} \cdot 6 \mathrm{H}_{2} \mathrm{O}$ ) and cleaned by washing with dilute $\mathrm{HCl}$. Analysis showed that the compound is anhydrous, but there is some doubt as to the correct formula. From the analyses of three preparations, the calculated ratio of SrO to $\mathrm{Al}_{2} \mathrm{O}_{3}$ ranged from 1.22 to 1.28. A ratio of 1.25 would correspond to the formula $5 \mathrm{SrO} \cdot 4 \mathrm{Al}_{2} \mathrm{O}_{3}$, which therefore is considered to be the most probable. This does not correspond to any previously reported compound. An attempt to prepare a compound of this ratio by heating the mixed oxides in air resulted in a mixture of $\mathrm{SrO} \cdot \mathrm{Al}_{2} \mathrm{O}_{3}$ and $3 \mathrm{SrO} \cdot \mathrm{Al}_{2} \mathrm{O}_{3}$.

Differential thermal analysis of a sample of the $5: 4$ aluminate revealed very small endothermic effects at 120,280 , and $480^{\circ} \mathrm{C}$. The first of these may indicate the expulsion of water from a trace of strontium hydroxide occluded in the crystals. The other two may be associated with a breakdown of the structure. $\mathrm{X}$-ray analysis of the sample after it had been heated up to $1,450^{\circ} \mathrm{C}$ showed only $\mathrm{SrO} \cdot \mathrm{Al}_{2} \mathrm{O}_{3}$ and $3 \mathrm{SrO} \cdot \mathrm{Al}_{2} \mathrm{O}_{3}$. The heat effects were not observed on reheating, but a new endothermic break appeared at $675^{\circ}$. The effect at $675^{\circ}$ appears to be due to an inversion characteristic of monostrontium aluminate, $\mathrm{SrO} \cdot \mathrm{Al}_{2} \mathrm{O}_{3}$, as it was duplicated in the heating curve of a sample of the latter compound.

The following optical properties of the 5:4 strontium aluminate were determined: Refractive indices, $\omega=1.644$ and $\epsilon=1.638$; character uniaxial negative. The X-ray diffraction pattern is given in table 2, together with a pattern for a sample of $\mathrm{SrO} \cdot \mathrm{Al}_{2} \mathrm{O}_{3}$. The latter was prepared by sintering a mixture of strontium carbonate and gibbsite, followed by fusion in an oxygen blast. It may be noted that the two patterns are quite dissimilar, indicating that the $5: 4$ 
compound is not merely a solid solution of $\mathrm{SrO}$ in $\mathrm{SrO} \cdot \mathrm{Al}_{2} \mathrm{O}_{3}$, as might have been inferred.

TABLE 2. Interplanar spacings and relative intensities of $X$-ray diffraction lines for certain strontium aluminates

\begin{tabular}{|c|c|c|c|c|c|c|}
\hline \multicolumn{3}{|c|}{$3 \mathrm{SrO} \cdot \mathrm{Al}_{2} \mathrm{O}_{3} \cdot 6 \mathrm{H}_{2} \mathrm{O}$} & \multicolumn{2}{|c|}{$5 \mathrm{SrO} \cdot 4 \mathrm{Al}_{2} \mathrm{O}_{3}$} & \multicolumn{2}{|c|}{$\mathrm{SrO} \cdot \mathrm{Al}_{2} \mathrm{O}_{3}$} \\
\hline$h k l$ a & $d$ & $I$ & $d$ & $I$ & $d$ & $I$ \\
\hline $\begin{array}{l}211 \\
321 \\
400 \\
420 \\
332\end{array}$ & $\begin{array}{c}A \\
\text { 5. } 32 \\
\text { 3. } 48 \\
3.26 \\
2.92 \\
2.78\end{array}$ & $\begin{array}{r}93 \\
86 \\
18 \\
100 \\
2\end{array}$ & $\begin{array}{c}A \\
4.53 \\
4.47 \\
3.68 \\
3.59 \\
3.48\end{array}$ & $\begin{array}{r}31 \\
41 \\
30 \\
2 \\
29\end{array}$ & $\begin{array}{c}A \\
6.09 \\
5.14 \\
4.44 \\
4.41 \\
4.02\end{array}$ & $\begin{array}{r}5 \\
3 \\
58 \\
30 \\
13\end{array}$ \\
\hline $\begin{array}{l}422 \\
510 \\
521 \\
440 \\
611\end{array}$ & $\begin{array}{l}\text { 2. } 66 \\
\text { 2. } 56 \\
\text { 2. } 381 \\
\text { 2. } 305 \\
\text { 2. } 115\end{array}$ & $\begin{array}{r}21 \\
10 \\
60 \\
8 \\
64\end{array}$ & $\begin{array}{l}3.25 \\
3.18 \\
3.05 \\
2.98 \\
2.84\end{array}$ & $\begin{array}{r}83 \\
100 \\
24 \\
88 \\
24\end{array}$ & $\begin{array}{l}3.91 \\
3.85 \\
3.54 \\
3.35 \\
3.14\end{array}$ & $\begin{array}{r}14 \\
11 \\
9 \\
4 \\
100\end{array}$ \\
\hline $\begin{array}{l}631 \\
444 \\
710 \\
640 \\
721\end{array}$ & $\begin{array}{l}\text { 1. } 924 \\
\text { 1. } 882 \\
\text { 1. } 845 \\
\text { 1. } 808 \\
\text { 1. } 774\end{array}$ & $\begin{array}{r}5 \\
12 \\
2 \\
35 \\
13\end{array}$ & $\begin{array}{l}2.75 \\
2.71 \\
2.63 \\
2.52 \\
2.48\end{array}$ & $\begin{array}{r}62 \\
32 \\
22 \\
6 \\
3\end{array}$ & $\begin{array}{l}3.05 \\
2.98 \\
2.57 \\
2.55 \\
2.47\end{array}$ & $\begin{array}{l}82 \\
73 \\
45 \\
71 \\
15\end{array}$ \\
\hline $\begin{array}{l}642 \\
732 \\
800 \\
653 \\
840\end{array}$ & $\begin{array}{l}\text { 1. } 743 \\
\text { 1. } 656 \\
\text { 1. } 630 \\
1.559 \\
\text { 1. } 458\end{array}$ & $\begin{array}{r}26 \\
13 \\
5 \\
4 \\
7\end{array}$ & $\begin{array}{l}2.41 \\
2.34 \\
\text { 2. } 30 \\
\text { 2. } 26 \\
\text { 2. } 20\end{array}$ & $\begin{array}{r}10 \\
7 \\
7 \\
7 \\
66\end{array}$ & $\begin{array}{l}2.42 \\
2.41 \\
2.37 \\
2.33 \\
2.32\end{array}$ & $\begin{array}{r}17 \\
14 \\
6 \\
5 \\
6\end{array}$ \\
\hline $\begin{array}{l}842 \\
921 \\
664 \\
932 \\
941\end{array}$ & $\begin{array}{l}\text { 1. } 422 \\
\text { 1. } 406 \\
\text { 1. } 390 \\
\text { 1. } 345 \\
\text { 1. } 317\end{array}$ & $\begin{array}{r}17 \\
9 \\
6 \\
7 \\
2\end{array}$ & $\begin{array}{l}\text { 2. } 16 \\
\text { 2. } 11 \\
\text { 2. } 10 \\
\text { 2. } 055 \\
\text { 2. } 051\end{array}$ & $\begin{array}{r}81 \\
14 \\
5 \\
33 \\
46\end{array}$ & $\begin{array}{l}\text { 2. } 224 \\
\text { 2. } 213 \\
\text { 2. } 205 \\
\text { 2. } 197 \\
\text { 2. } 188\end{array}$ & $\begin{array}{l}22 \\
10 \\
16 \\
15 \\
13\end{array}$ \\
\hline $\begin{array}{l}10 \cdot 1 \cdot 1 \\
10 \cdot 2 \cdot 0 \\
10 \cdot 3 \cdot 1 \\
10 \cdot 4 \cdot 0 \\
10 \cdot 3 \cdot 3\end{array}$ & $\begin{array}{l}\text { 1. } 291 \\
\text { 1. } 278 \\
\text { 1. } 243 \\
\text { 1. } 210 \\
\text { 1. } 200\end{array}$ & $\begin{array}{r}3 \\
2 \\
7 \\
12 \\
3\end{array}$ & $\begin{array}{l}\text { 2. } 007 \\
\text { 1. } 971 \\
\text { 1. } 966 \\
\text { 1. } 946 \\
\text { 1. } 909\end{array}$ & $\begin{array}{r}3 \\
21 \\
12 \\
40 \\
3\end{array}$ & $\begin{array}{l}2.155 \\
2.141 \\
2.106 \\
2.027 \\
2.010\end{array}$ & $\begin{array}{r}16 \\
8 \\
20 \\
6 \\
14\end{array}$ \\
\hline $\begin{array}{r}10 \cdot 4 \cdot 2 \\
11 \cdot 2 \cdot 1 \\
8 \cdot 8 \cdot 0 \\
11 \cdot 3 \cdot 2 \\
9 \cdot 6 \cdot 5\end{array}$ & $\begin{array}{l}\text { 1. } 190 \\
\text { 1. } 162 \\
1.152 \\
1.126 \\
\text { 1. } 094\end{array}$ & $\begin{array}{r}15 \\
10 \\
4 \\
4 \\
3\end{array}$ & 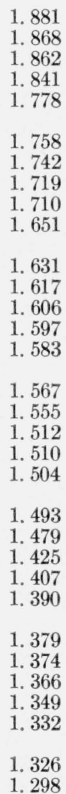 & $\begin{array}{r}43 \\
8 \\
5 \\
5 \\
1 \\
13 \\
13 \\
9 \\
15 \\
5 \\
3 \\
\\
21 \\
2 \\
19 \\
7 \\
12 \\
\\
10 \\
2 \\
4 \\
6 \\
8 \\
\\
3 \\
9 \\
1 \\
1 \\
15 \\
13 \\
13 \\
3 \\
3 \\
4 \\
8 \\
\end{array}$ & $\begin{array}{l}\text { 1. } 953 \\
\text { 1. } 926 \\
\text { 1. } 911 \\
\text { 1. } 901 \\
\text { 1. } 867\end{array}$ & $\begin{array}{r}18 \\
25 \\
8 \\
11 \\
13\end{array}$ \\
\hline
\end{tabular}

s Where more than one set of indices is possible, only one is given.

\section{3. $3 \mathrm{CaO} \cdot \mathrm{Al}_{2} \mathrm{O}_{3}-3 \mathrm{SrO} \cdot \mathrm{Al}_{2} \mathrm{O}_{3}$ Solid Solutions}

The existence of a strontium compound isomorphous with tricalcium aluminate hexahydrate having been established, it was of interest to try to prepare members of a solid solution series intermediate between the two. For this purpose anhydrous sinters were

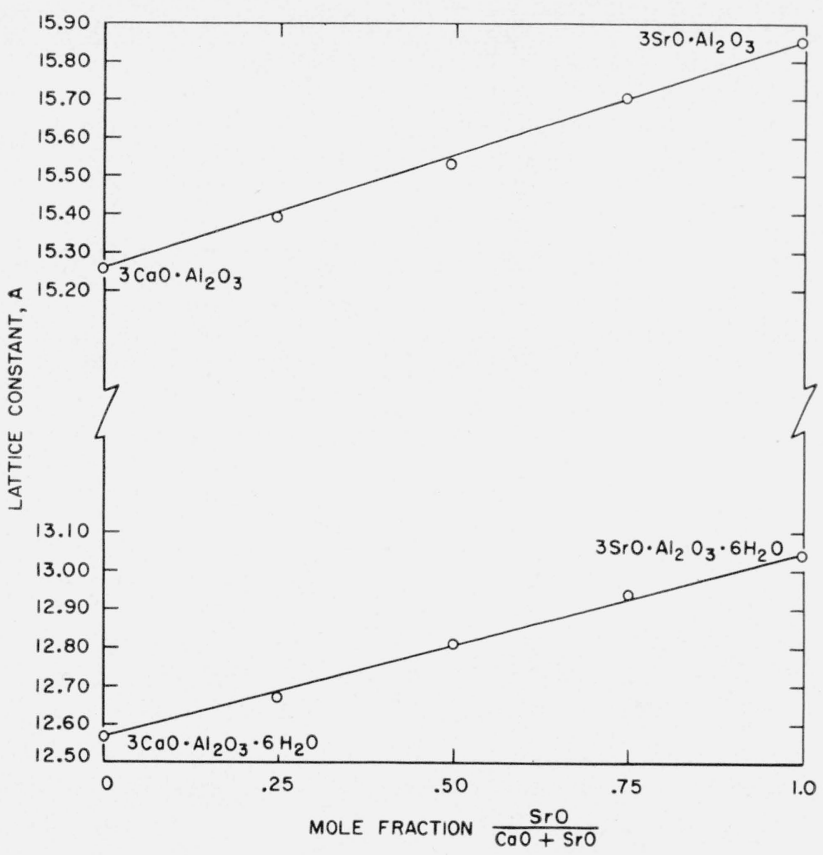

Figure 3. Dimensions of unit cells for members of the $3 \mathrm{CaO} \cdot \mathrm{Al}_{2} \mathrm{O}_{3}-3 \mathrm{SrO} \cdot \mathrm{Al}_{2} \mathrm{O}_{3}$ solid-solution series and the $3 \mathrm{CaO} \cdot \mathrm{Al}_{2} \mathrm{O}_{3} \cdot 6 \mathrm{H}_{2} \mathrm{O}-3 \mathrm{SrO} \cdot \mathrm{Al}_{2} \mathrm{O}_{3} \cdot 6 \mathrm{H}_{2} \mathrm{O}$ solid-solution series.

prepared of $3 \mathrm{CaO} \cdot \mathrm{Al}_{2} \mathrm{O}_{3}, 3 \mathrm{SrO} \cdot \mathrm{Al}_{2} \mathrm{O}_{3}$, and three intermediate compositions having $\mathrm{CaO}: \mathrm{SrO}$ ratios of $3: 1$, $1: 1$, and $1: 3$, respectively. These were prepared by mixing the alkaline earth carbonates with gibbsite in the desired proportions and heating at $1,450^{\circ} \mathrm{C}$. The products were ground and reburned at 1,470 to $1,500^{\circ}$, but were still not completely homogenous. $\mathrm{X}$-ray powder diffraction patterns were all similar, exhibiting a regular shift in passing from the calcium to the strontium compound. The end members of the series have been shown to belong to the cubic system [11]. On this basis, the unit cell dimension was calculated from the spacings. The relation between composition and unit cell size is shown in figure 3. The ratio of unit cell edge of the strontium compound to that of the calcium compound is 1.038.

\section{4. $3 \mathrm{CaO} \cdot \mathrm{Al}_{2} \mathrm{O}_{3} \cdot 6 \mathrm{H}_{2} \mathrm{O}-3 \mathrm{SrO} \cdot \mathrm{Al}_{2} \mathrm{O}_{3} \cdot 6 \mathrm{H}_{2} \mathrm{O}$ Solid Solutions}

The anhydrous sinters described above were treated hydrothermally at about $160^{\circ} \mathrm{C}$. The product in each case was isotropic, and the X-ray diffraction patterns formed a regular series, as in the case of the anhydrous sinters. The relation between composition and unit cell edge is shown in figure 3. The relationship is linear, as was the case with the anhydrous solid solution series, and the ratio of the lattice constants for the end members is 1.037 .

An attempt was made to prepare an intermediate $3(\mathrm{Ca}, \mathrm{Sr}) \mathrm{O} \cdot \mathrm{Al}_{2} \mathrm{O}_{3} \cdot 6 \mathrm{H}_{2} \mathrm{O}$ composition by direct hydrothermal treatment of the mixed oxides. This was unsuccessful. The X-ray pattern of the product indicated two separate solid solution members, one close to the calcium and the other to the strontium end. It is reasonable to assume that the strontia reacted first, by reason of its higher solubility, leaving a solution richer in lime to react later. 
It has been noted that under hydrothermal conditions the calcium aluminate hydrate breaks down at about $215^{\circ} \mathrm{C}$ to form $4 \mathrm{CaO} \cdot 3 \mathrm{Al}_{2} \mathrm{O}_{3} \cdot 3 \mathrm{H}_{2} \mathrm{O}$ and $\mathrm{Ca}(\mathrm{OH})_{2}$, also that the strontium compound may decompose at somewhat higher temperatures, forming a variety of products. It remains to be seen how the intermediate members behave in this respect. Table 3 (Nos. 17 to 24 and 5,6) gives the data for pairs of hydrothermal experiments bracketing the decomposition temperatures for the 5 compositions described above. The data for experiments 5 and 6 , table 1 , are repeated here for comparison. The range of stability increases with the strontium content. The mechanism of the decomposition of the third and fourth members of the series is still somewhat obscure, but for the second member, with strontia constituting one-fourth of the alkaline earth present, the course of the reactions is fairly clear. The data for experiments 25 to 28 in table 3 serve to illustrate the nature of the process. In this series the temperature was kept approximately constant, while the duration of treatment was varied. The temperature used was well above the decomposition temperature (approximately $228^{\circ} \mathrm{C}$, as indicated by experiment 20). The data for No. 25 show that the anhydrous sinter was essentially all converted to the hexahydrate during the 4-hour period in which the temperature was raised from room temperature to $265^{\circ} \mathrm{C}$. No. 26 was held for $90 \mathrm{~min}$ at $278^{\circ}$ following the warmup period. This preparation gave an X-ray pattern indicating two distinct isometric phases of the same structure but different lattice constants. The predominant phase had a unit cell edge of $12.66 \mathrm{~A}$, substantially in agreement with the size of the cell in preparations 19 and 20 . The other phase had a unit cell edge of $12.83 \mathrm{~A}$, indicative of a much higher strontium content (see fig. 3). Lines of calcium hydroxide and $4 \mathrm{CaO} \cdot 3 \mathrm{Al}_{2} \mathrm{O}_{3} \cdot 3 \mathrm{H}_{2} \mathrm{O}$ were also present in the X-ray pattern. The data for No. 27 indicate increased conversion to the strontium-rich phase with longer hydrothermal treatment. Finally, after 7 days (No. 28) the original isometric phase had disappeared. It should be noted that the change from the calcium-rich to the strontium-rich isometric phase is abrupt; that is, there is not a gradual shift in the position of the X-ray lines. It may reasonably be concluded that the initial calcium-rich phase (probably formed during the warmup period) goes into solution, from which $\mathrm{Ca}(\mathrm{OH})_{2}, 4 \mathrm{CaO} \cdot 3 \mathrm{Al}_{2} \mathrm{O}_{3} \cdot 3 \mathrm{H}_{2} \mathrm{O}$, and the strontium-rich isometric phase are then precipitated. The slight variation in the reported unit cell size for the initially-formed isometric phase, 12.65 to $12.69 \mathrm{~A}$, is believed not to be significant. On the other hand, the range from 12.83 to $12.92 \mathrm{~A}$ for the other phase is rather too large to be attributed to experimental error. It probably reflects an actual difference in composition, but whether systematic or accidental cannot be determined without further data.

The mechanism of decomposition is believed to be essentially the same for the other two calciumstrontium compositions, in the initial stage. Calcium hydroxide was identified in the products of experiments 22 and 24 , table 3 , and there were some crystals having the general appearance and the refractive index of $4 \mathrm{CaO} \cdot 3 \mathrm{Al}_{2} \mathrm{O}_{3} \cdot 3 \mathrm{H}_{2} \mathrm{O}$. The latter compound was insufficient in quantity to affect the $\mathrm{X}$-ray pattern. At higher temperatures the X-ray patterns showed evidence of the presence of other phases which were not identified. The reactions giving rise to these were not investigated further.

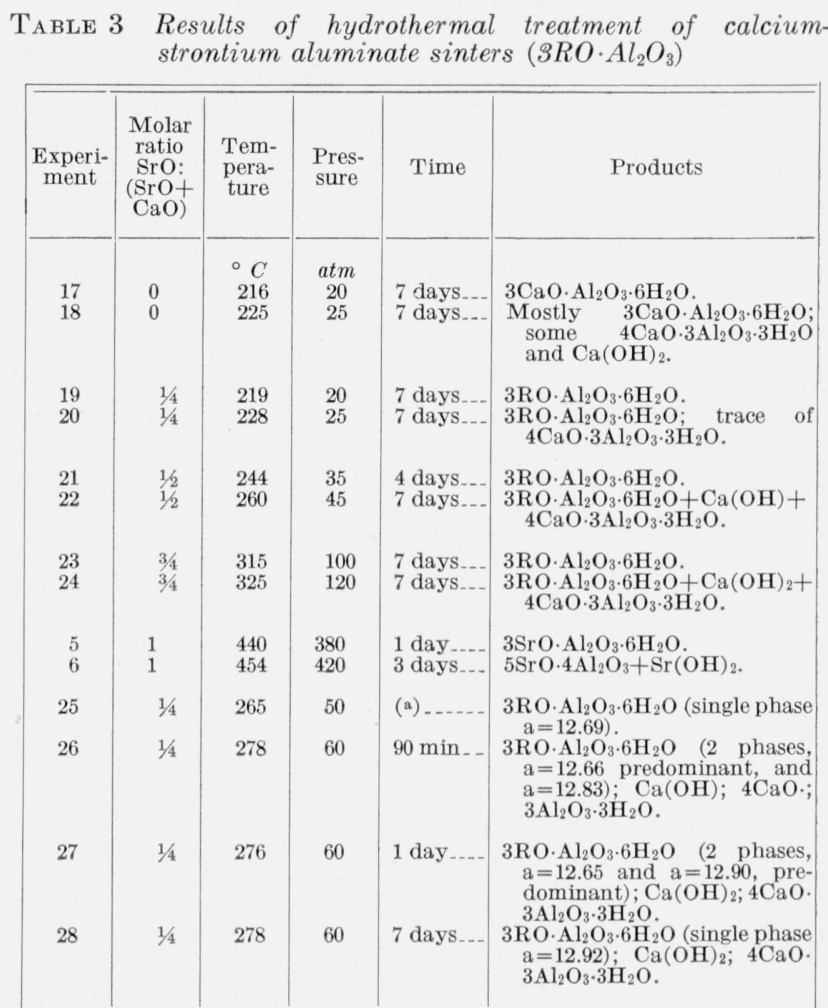

a Cooled immediately after temperature reached $265^{\circ}$; duration of warmup period, $4 \mathrm{hr}$.

\subsection{Attempts to Prepare a Strontia-Alumina-Silica Hydrogarnet}

One of the primary aims of the present study was to ascertain whether strontium hydrogarnets analogous to the $3 \mathrm{CaO} \cdot \mathrm{Al}_{2} \mathrm{O}_{3} \cdot 6 \mathrm{H}_{2} \mathrm{O}-3 \mathrm{CaO} \cdot \mathrm{Al}_{2} \mathrm{O}_{3} \cdot 3 \mathrm{SiO}_{2}$ series could be prepared. Numerous experiments were carried out in an attempt to replace part of the water of $3 \mathrm{SrO} \cdot \mathrm{Al}_{2} \mathrm{O}_{3} \cdot 6 \mathrm{H}_{2} \mathrm{O}$ by silica. The methods used were those which have been successfully employed in preparing the calcium hydrogarnets.

Table 4 gives a few representative data indicating the range of experimental conditions and the type of products obtained. Tristrontium aluminate hexahydrate was identified in the products of Nos. 29 to 32 and 37 . In every case the unit cell edge, calculated from the X-ray diffraction pattern, was the same as that for the pure compound, within the limits of experimental error. On the basis of analogy with the lime-alumina-silica hydrogarnets [2] it may be estimated that substitution of as little as one-tenth mole of $\mathrm{SiO}_{2}$ in the structure would result in a measurable change in the lattice constant. It is therefore concluded that little or no silica was taken up into the strontium aluminate hexahydrate structure. Experiment No. 37, unlike the others, was performed 
TABLE 4. Results of experiments with reaction mixtures containing strontia, alumina, silica, and water.

\begin{tabular}{|c|c|c|c|c|c|c|}
\hline Experiment & Reactants (solid) & $\begin{array}{c}\text { Molar ratio } \\
\mathrm{SrO}: \mathrm{Al}_{2} \mathrm{O}_{3}: \mathrm{SiO}_{2}\end{array}$ & $\begin{array}{l}\text { Tempera- } \\
\text { ture }\end{array}$ & Pressure & Time & Products \\
\hline 29 & Glass ..... & $3: 1: 1 / 2$ & ${ }^{\circ} \mathrm{C}$ & atm & $\begin{array}{l}\text { Days } \\
6\end{array}$ & $3 \mathrm{SrO} \cdot \mathrm{Al}_{2} \mathrm{O}_{3} \cdot 6 \mathrm{H}_{2} \mathrm{O}$ and small amount of \\
\hline 30 & ...... do & $3: 1: 1 / 2$ & 244 & 35 & 6 & unrO $\mathrm{Al}_{2} \mathrm{O}_{3} \cdot 6 \mathrm{H}_{2} \mathrm{O}$ and unidentified mate- \\
\hline 31 & ...... do & $3: 1: 1$ & 152 & 5 & 7 & $3 \mathrm{SrO} \cdot \mathrm{Al}_{2} \mathrm{O}_{3} \cdot 6 \mathrm{H}_{2} \mathrm{O}$ and unidentified mate- \\
\hline 32 & $3 \mathrm{SrO} \cdot \mathrm{Al}_{2} \mathrm{O}_{3} \cdot 6 \mathrm{H}_{2} \mathrm{O}+\mathrm{SiO}_{2}$ gel $\ldots$ & $3: 1: 1$ & 203 & 16 & 42 & $3 \mathrm{SrO} \cdot \mathrm{Al}_{2} \mathrm{O}_{3} \cdot 6 \mathrm{H}_{2} \mathrm{O}$ and unidentified mate- \\
\hline 33 & $3 \mathrm{SrO} \cdot 2 \mathrm{SiO}_{2} \cdot 4 \mathrm{H}_{2} \mathrm{O}+\mathrm{Al}_{2} \mathrm{O}_{3} \cdot 3 \mathrm{H}_{2} \mathrm{O} \ldots \ldots$. & $3: 1: 2$ & 190 & 12 & 7 & Unidentified; at least 2 phases present. \\
\hline 34 & $\mathrm{Sr}(\mathrm{OH})_{2} \cdot 8 \mathrm{H}_{2} \mathrm{O}+$ activated kaolin......... & $3: 1: 2$ & 376 & 220 & 7 & $\mathrm{SrO} \cdot \mathrm{SiO}_{2}$ and unidentified material. \\
\hline 35 & Glass & $3: 1: 3$ & 249 & 39 & 7 & Unidentified; at least 2 phases present. \\
\hline 36 & $\mathrm{Sr}(\mathrm{OH})_{2} \cdot 8 \mathrm{H}_{2} \mathrm{O}+\mathrm{Al}_{2} \mathrm{O}_{3} \cdot 3 \mathrm{H}_{2} \mathrm{O}+\mathrm{SiO}_{2}$ gel $\ldots$ & $3: 1: 3$ & 300 & 85 & 7 & $\mathrm{SrO} \cdot \mathrm{SiO}_{2}$ and unidentified material. \\
\hline 37 & $\begin{array}{l}\mathrm{NaAlO}_{2}+\mathrm{Na}_{2} \mathrm{SiO}_{3}+\mathrm{Sr}(\mathrm{OH})_{2} \text { (all in solu- } \\
\text { tion). }\end{array}$ & 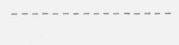 & 100 & 1 & & $3 \mathrm{SrO} \cdot \mathrm{Al}_{2} \mathrm{O}_{3} \cdot 6 \mathrm{H}_{2} \mathrm{O}+3 \mathrm{SrO} \cdot 2 \mathrm{SiO}_{2} \cdot 3 \mathrm{H}_{2} \mathrm{O}$ \\
\hline
\end{tabular}

by boiling a mixed solution of the reactants in a flask at atmospheric pressure. The reaction was complete in a few minutes, and the product consisted of $3 \mathrm{SrO} \cdot \mathrm{Al}_{2} \mathrm{O}_{3} \cdot 6 \mathrm{H}_{2} \mathrm{O}$ and $3 \mathrm{SrO} \cdot 2 \mathrm{SiO}_{2} \cdot 3 \mathrm{H}_{2} \mathrm{O}$, both well crystallized. In the experiments at higher temperatures and pressures, the siliceous phases were not identified, except that in certain cases $\mathrm{SrO} \cdot \mathrm{SiO}_{2}$ was detected both microscopically and by X-ray diffraction analysis. The rest of the lines on the X-ray patterns failed to fit any known patterns for compounds that might conceivably have been present. It is assumed, therefore, that compounds were formed containing all three oxides, $\mathrm{SrO}, \mathrm{Al}_{2} \mathrm{O}_{3}$, and $\mathrm{SiO}_{2}$, and possibly $\mathrm{H}_{2} \mathrm{O}$. The variation in the optical properties and $\mathrm{X}$-ray patterns indicated that at least 2 and probably 3 such compounds were present in the various preparations. Identification probably would involve a thorough study of the system $\mathrm{SrO}-\mathrm{Al}_{2} \mathrm{O}_{3}-\mathrm{SiO}_{2}-\mathrm{H}_{2} \mathrm{O}$, which is beyond the scope of the present investigation.

The essential conclusion to be drawn from this set of experiments is that $3 \mathrm{SrO} \cdot \mathrm{Al}_{2} \mathrm{O}_{3} \cdot 6 \mathrm{H}_{2} \mathrm{O}$ will not take up any appreciable amount of silica, but instead will react with silica present in the system to form a strontium silicate or perhaps one or more $\mathrm{SrO}-\mathrm{Al}_{2} \mathrm{O}_{3}$ $\mathrm{SiO}_{2}$ compounds.

\section{Summary}

In this investigation of compounds formed in the system strontia-alumina-water, the only hydrated strontium aluminate definitely identified was $3 \mathrm{SrO} \cdot \mathrm{Al}_{2} \mathrm{O}_{3} \cdot 6 \mathrm{H}_{2} \mathrm{O}$. This compound was readily prepared by various methods at temperatures ranging from room temperature to $440^{\circ} \mathrm{C}$. It crystallizes in the isometric system, with a unit cell of $13.04 \mathrm{~A}$, and has a refractive index of 1.588 . It is isomorphous with $3 \mathrm{CaO} \cdot \mathrm{Al}_{2} \mathrm{O}_{3} \cdot 6 \mathrm{H}_{2} \mathrm{O}$ and a complete series of solid solutions exists between the two.

The strontium aluminate hydrate decomposes under hydrothermal conditions at temperatures as low as $305^{\circ} \mathrm{C}$ at $2 \mathrm{~atm}$ pressure, and $454^{\circ}$ at 420 atm. The products of decomposition appear to depend on both temperature and pressure, but a given set of conditions did not always produce the same results. In a few instances a product was formed which is believed to be a lower hydrate, probably with 1.5 molecules of water. In most cases decomposition occurred with liberation of strontium hydroxide. One of the products in several experiments was a coarsely crystalline anhydrous strontium aluminate having the approximate composition $5 \mathrm{SrO} \cdot 4 \mathrm{Al}_{2} \mathrm{O}_{3}$. This compound, not previously reported, crystallizes in the form of hexagonal prisms, with refractive indices $\omega=1.644, \epsilon=1.638$. It decomposes on heating, with formation of $\mathrm{SrO} \cdot \mathrm{Al}_{2} \mathrm{O}_{3}$ and $3 \mathrm{SrO} \cdot \mathrm{Al}_{2} \mathrm{O}_{3}$.

The stability range of tristontium aluminate hexahydrate is higher than that of the corresponding calcium compound, which decomposes at about $215^{\circ} \mathrm{C}$. Intermediate members of the solid solution series break down at intermediate temperatures, apparently with precipitation of most of the calcium as hydroxide and $4 \mathrm{CaO} \cdot 3 \mathrm{Al}_{2} \mathrm{O}_{3} \cdot 3 \mathrm{H}_{2} \mathrm{O}$, accompanied by formation of a solid solution richer in strontium.

Attempts were made to prepare a strontia-aluminasilica hydrogarnet, but without success. The product obtained had the properties of $3 \mathrm{SrO} \cdot \mathrm{Al}_{2} \mathrm{O}_{3} \cdot 6 \mathrm{H}_{2} \mathrm{O}$, indicating that no appreciable amount of silica had been taken into solid solution.

The X-ray diffraction patterns for this study were made by G. M. Ugrinic, the photomicrographs by F. A. Heckman, and the differential thermal analyses by E. S. Newman. The author acknowledges their assistance with thanks.

\section{References}

[1] T. Thorvaldson, N. S. Grace, and V. A. Vigfusson, Can. J. Res. 1, 201 (1929).

[2] E. P. Flint, H. F. McMurdie, and L. S. Wells, J. Research NBS 26, 13 (1941) RP1355.

[3] L. S. Wells, W. F. Clarke, and H. F. MeMurdie, J. Research NBS 30, 367 (1943) RP1539.

[4] E. T. Carlson and L. S. Wells, J. Research NBS 51, 73 (1953) RP 2433.

[5] E. Brandenberger, Schweiz. mineralog. petrog. Mitt. 13, 569 (1933).

[6] G. Maekawa, J. Soc. Chem. Ind. Japan 45, 751 (1943); Chem. Abstr. 43, 1278 (1949).

[7] G. C. Kennedy, Am. J. Sci. 248, 540 (1950).

[8] H. Johnson and T. Thorvaldson, Can. J. Res. 21, 236 (1943).

[9] R. B. Peppler and L. S. Wells, J. Research NBS 52, 75 (1954) RP2476.

[10] E. G. Swenson and T. Thorvaldson, Can. J. Chem. 30, 257 (1952)

[11] K. Lagerqvist, S. Wallmark, and A. Westgren, Z. anorg. u. allgem. Chem. 234, 1 (1937).

Washington, December 15, 1954. 